\title{
Thermal Conductivity of RDX
}

\author{
B. D. Faubion
}

DEVELOPMENT DIVISION

NOVEMBER 1976

P. O. NO. 03-5541

\section{Pllot}

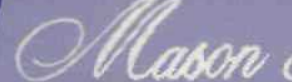

OPantear OPlant

O. BOX 30020

AMARILLO. TEXAS 79177

806.335 1581

ENERGY RESEARCH AND DEVELORMENT ADMINISTRATIOS

I S GOVERIMENT ContraCt EY 7GGC 04.04E?

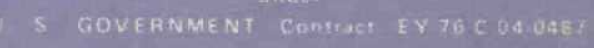


NOTICE

This report was prepared as an account of work sponsored by the United States Government. Neither the United States nor the United States Energy Research and Development Administration, nor their employees, nor any of their contractors, subcontractors, or their employees, makes any warranty, express or implied, or assumes any legal liability or responsibility for the accuracy, completeness or usefulness of any information, apparatus, product or process disclosed, or represents that its use would not infringe privately-owned rights. 


\section{DISCLAIMER}

This report was prepared as an account of work sponsored by an agency of the United States Government. Neither the United States Government nor any agency Thereof, nor any of their employees, makes any warranty, express or implied, or assumes any legal liability or responsibility for the accuracy, completeness, or usefulness of any information, apparatus, product, or process disclosed, or represents that its use would not infringe privately owned rights. Reference herein to any specific commercial product, process, or service by trade name, trademark, manufacturer, or otherwise does not necessarily constitute or imply its endorsement, recommendation, or favoring by the United States Government or any agency thereof. The views and opinions of authors expressed herein do not necessarily state or reflect those of the United States Government or any agency thereof. 


\section{DISCLAIMER}

Portions of this document may be illegible in electronic image products. Images are produced from the best available original document. 


\title{
Thermal Conductivity of RDX
}

\author{
B. D. Faubion \\ DEVELOPMENT DIVISION \\ November 1976 \\ P.O. No. 03-5541 \\ For \\ Sandia Laboratories \\ Albuquerque, New Mexico
}

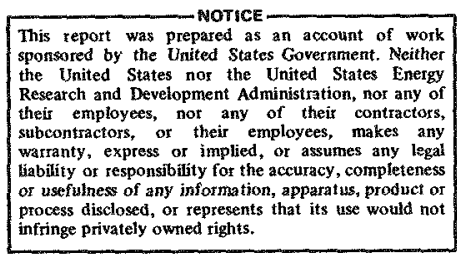

$-1-$ 
The thermal conductivity of RDX was determined at $222,293,347,394$ and $450 \mathrm{~K}$. The thermal diffusivity of pellets pressed to four different densities was measured using the pulse heating method. The specific heat was measured at each temperature using the DSC method. The thermal conductivity was calculated from the thermal diffusivity, density and specific heat.

\section{INTRODUCTION}

The pulsed method for measuring thermal diffusivity is well documented $(1,2,3,4,5)$. An adaptation of this technique has been used to measure the thermal diffusivity of the explosive hexanitrostilbene (HNS) as a function of temperature(6).

\section{EXPERTMENTAL PROCEDURE}

Details of the apparatus and experimental procedure have been given previously $(6)$. A cutaway of the test chamber and a block diagram of the setup is shown in Fig. 1.

The specific heat was determined using the standard procedure for the Perkin-Elmer Differential Scanning Calorimeter Model DSC-I(?).

The RDX (Ensign Bickford Lot ENB-01-01) was pressed in a $1.27 \mathrm{~cm}$ diameter die on the Dead Weight Press to four different densities. The pellets were approximately $0.13 \mathrm{~cm}$ thick so that edge loss effects were insignificant.

\section{RESULTS AND DISCUSSION}

The specific heat of RDX at five temperatures is listed in Table I, The values are the average of two runs which were within $\pm 2 \%$ of the average. A plot of the specific heat as a function of absolute temperature is shown in Fig. 2 .

The thermal diffusivity for the four densities at each temperature is listed in Table II. The thermal diffusivity was determined by analysis of the temperature-time plots of the rear surface temperature. The diffusivity was corrected for finite pulse time and heat-1oss effects using Heckman's tables (8).

The thermal conductivity was calculated using the corrected thermal diffusivity, the density and the specific heat at each temperature. The results are tabulated in Table III. Each value is the average of three rums and the sigma ranges from approximately $\pm 3 \%$ near room temperature to $\pm 10 \%$ at the two temperature extremes. The results are graphically illustrated in Fig. 3. There is no consistent trend for the therma1 conductivity of the various density pellets at each temperature. If the average thermal conductivity at each temperature is plotted a smooth 
curve can be drawn. This curve shows a minimum at approximately $273 \mathrm{~K}$ $(0 \mathrm{C})$. This may be related to the presence of moisture which would result in the formation of frost. The thermal conductivity of ice increases with decreasing temperature and is 30 to 50 times greater than the values being measured; therefore, the increase in thermal conductivity from $293 \mathrm{~K}$ to $222 \mathrm{~K}$ could be accounted for by as little as $0.15 \%$ ice.

The average value of the thermal conductivity at $450 \mathrm{~K}$ is $2.3 \times 10^{-4}$ cal cm$~^{-1} \mathrm{sec}^{-1} \mathrm{deg}^{-1}$ for an average density of $1.575 \mathrm{~g} \mathrm{~cm}^{-3}$. This value is in fair agreement with the value given by Rogers (9) of 2.53 $\times 10^{-4} \mathrm{cal} \mathrm{cm}^{-1} \mathrm{sec}^{-1} \mathrm{deg}^{-1}$ for a density of $1.533 \mathrm{~g} \mathrm{~cm}^{-3}$. 

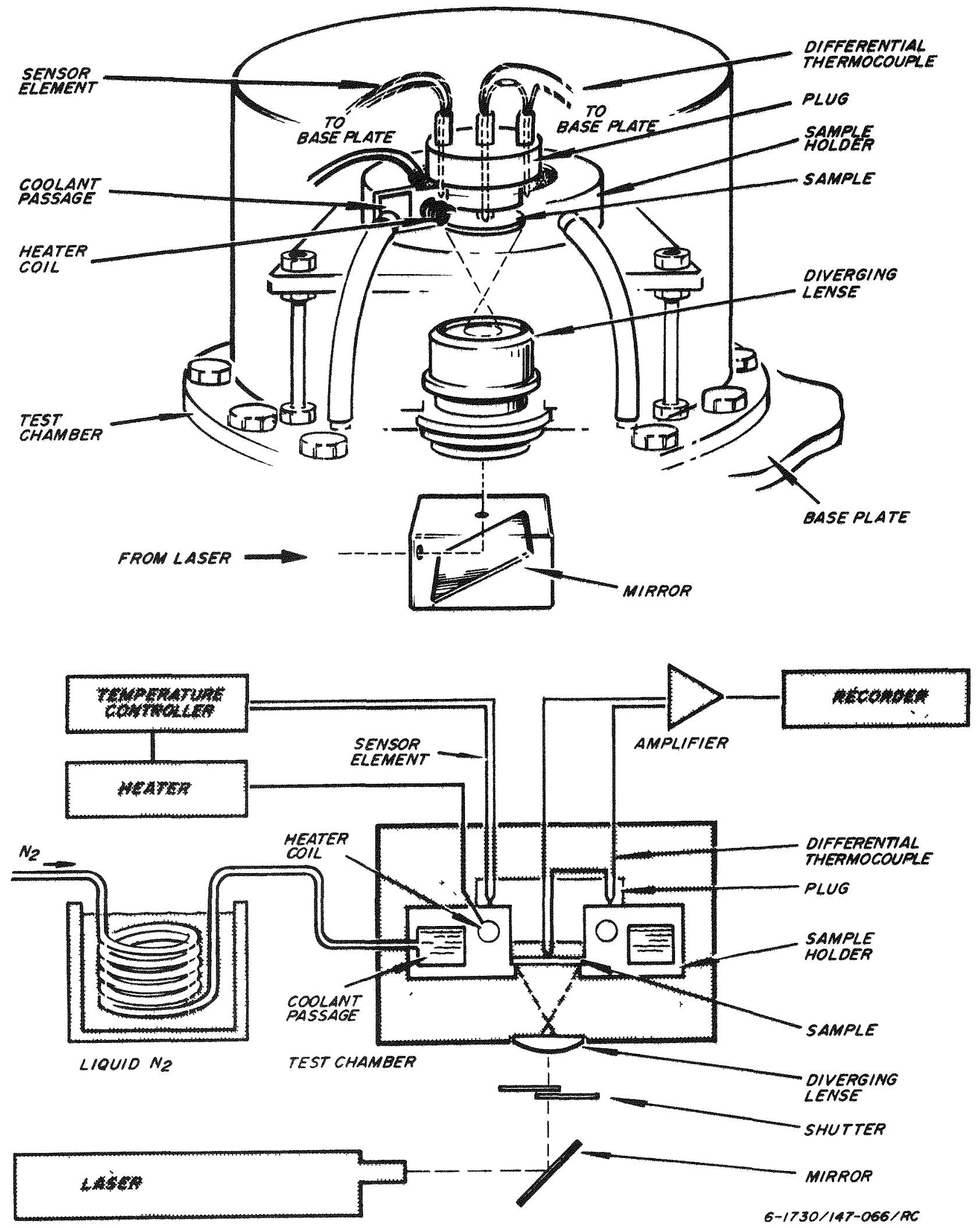

Fig. 1. Test Chamber and Block Diagram of Thermal Diffusivity Apparatus 
Table I. Specific Heat of $\mathrm{RDX}$

$\underline{T(K)}$

222

293

347

394

450
$\mathrm{C}\left(\mathrm{cal} \mathrm{g} \mathrm{g}^{-1} \mathrm{deg}^{-1}\right)$

0.207

0.239

0.265

0.313

0.351

Table II. Thermal Diffusivity of RDX (ENB-01-01)

\begin{tabular}{|c|c|c|c|c|c|}
\hline \multirow[b]{2}{*}{$\begin{array}{l}\text { Temp. } \\
(\mathrm{K})\end{array}$} & \multicolumn{5}{|c|}{$\left(\lambda \times 10^{4}\right) \mathrm{cm}^{2} \mathrm{sec}^{-1}$} \\
\hline & $\rho\left(\mathrm{g} \mathrm{cm}^{-3}\right):$ & $\frac{0.1341}{1.6604}$ & $\frac{0.1372}{1.6347}$ & $\frac{0.1252}{1.5701}$ & $\begin{array}{l}0.1397 \\
1.4350\end{array}$ \\
\hline 222 & & 4.50 & 6.27 & 3.72 & 6.62 \\
\hline 293 & & 4.41 & 5.04 & 4.02 & 3.97 \\
\hline 347 & & 3.14 & 3.96 & 5.43 & 4.27 \\
\hline 394 & & 4.03 & 3.66 & 5.21 & 3.86 \\
\hline 450 & & 3.83 & 3.84 & 5.00 & 3.98 \\
\hline
\end{tabular}

Table III. Thermal Conductivity of RDX (ENB-01-01)

\begin{tabular}{|c|c|c|c|c|c|}
\hline \multirow[b]{2}{*}{$\begin{array}{l}\text { Temp. } \\
(\mathrm{K})\end{array}$} & \multirow[b]{2}{*}{$\begin{aligned} & \ell(\mathrm{cm}):: \\
&\left.\rho(\mathrm{g} \mathrm{cm})^{-3}\right):\end{aligned}$} & \multicolumn{4}{|c|}{. $\quad\left(\lambda \times 10^{4}\right) \mathrm{cal} \mathrm{cm}^{-1} \mathrm{sec}^{-1} \mathrm{deg}^{-1}$} \\
\hline & & $\begin{array}{l}0.1341 \\
1.6604 \\
\end{array}$ & 0.1372 & $\frac{0.1252}{1.5701}$ & $\begin{array}{l}0.1397 \\
1.4350\end{array}$ \\
\hline 222 & & 1.55 & 2.12 & 1.21 & 1.97 \\
\hline 293 & & 1.75 & 1.98 & 1.51 & 1.36 \\
\hline 347 & & 1.38 & 1.71 & 2.26 & 1.62 \\
\hline 394 & & 2.09 & 2.07 & 2.56 & 1.74 \\
\hline 450 & & 2.24 & 2.20 & 2.76 & 2.00 \\
\hline
\end{tabular}




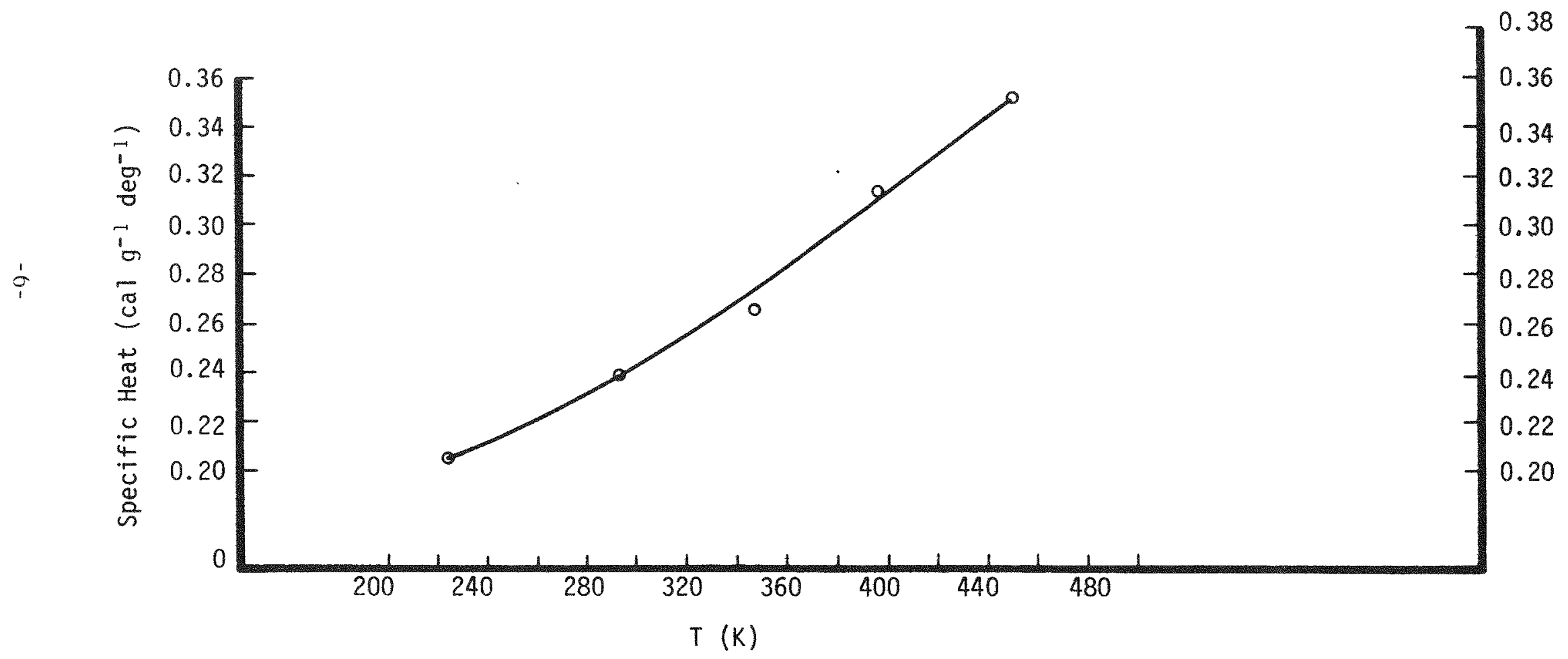

Fig. 2. Specific Heat of RDX as a Function of Absolute Temperature 


$\begin{array}{lll} & \frac{\ell \mathrm{cm}}{13716} & \frac{\rho \mathrm{g} \mathrm{cm}^{-3}}{1.6347} \\ 0 & 0.1252 & 1.5701 \\ 0 & 0.134112 & 1.6604 \\ 0.1397 & 1.435\end{array}$

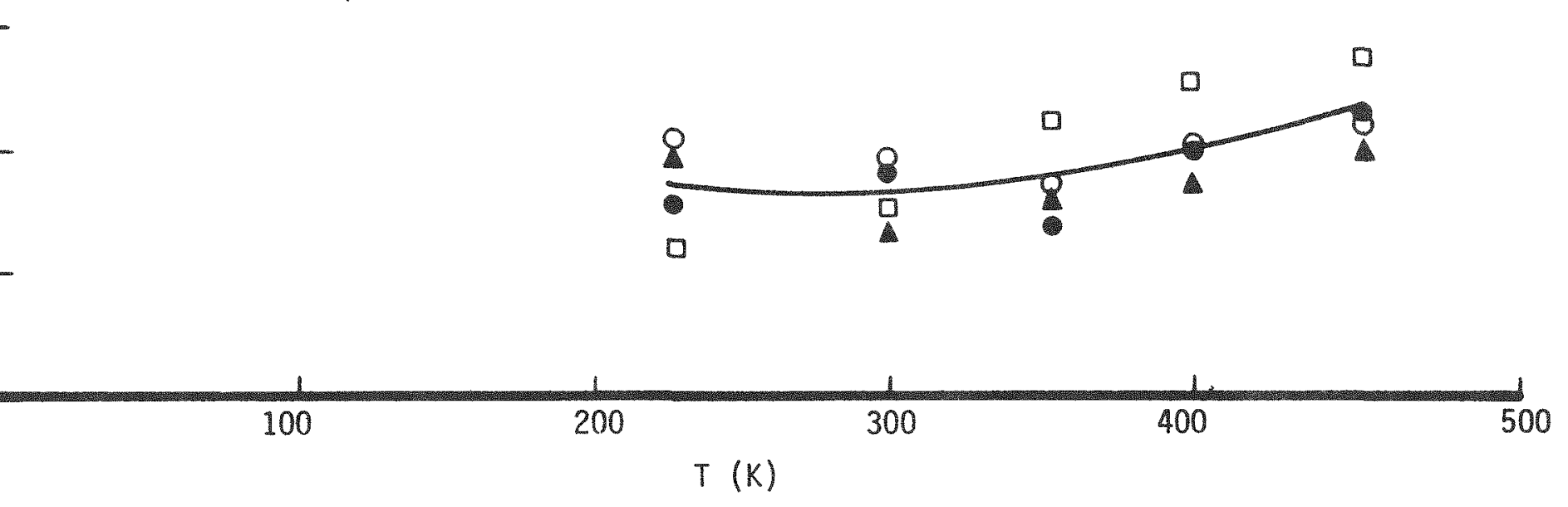

Fig. 3. Thermal Conductivity of RDX 


\section{REFERENCES}

1. W. T. Parker, et.a1., U. S. Navy Radiological Defense Laboratory, USNLRDL-TR-424, May 1960.

2. R. L. Rudkin, R. J. Jenkins and W. J. Parker, Rev. Sci. Instr., 33 (1962) 21 .

3. H. W. Deem and W. D. Wood, Rev. Sci. Instr., 33 (1962) 1107.

4. J. T. Schriempf, Report of NRL Progress (February 1972) 9.

5. V. I. Chistyskov, Teplofizika Vysokikh Temperatus, 11 (1973) 832.

6. B. D. Faubion, "Thermal Conductivity of HNS," MHSMP-76-16 (March 1976).

7. Thermal Analysis Newsletter, No. 3 Perkin-Elmer Corporation, Norwa1k, Connecticut.

8. R. C. Heckman, J. App1.Phys., 44 (1973) 1455.

9. Raymond R. Rogers, Thermochemica Acta, 11 (1975) 131. 